\title{
Changes in the Legal Agency Status of the Pakuan Bogor Regional Legal Company in Improving Drinking Water Services in Bogor City based on Government Regulation Number 54 of 2017 Concerning Local Government Owned Enterprises (BUMD)
}

\author{
Nazaruddin Lathif; Mustika Mega Wijaya; Raden Muhammad Mihradi \\ Lecturers of Faculty of Law, Universitas Pakuan, Indonesia \\ http://dx.doi.org/10.18415/ijmmu.v8i1.2301
}

\begin{abstract}
The idea of establishing a Local Government-Owned Enterprise (BUMD) departs from an ideological perspective regarding the concept of a welfare law state that emerged after the 19th century. The teaching emphasizes that the state must intervene in the socio-economic life of society for the welfare of its citizens. One form of intervention is through the authority to form State-Owned Enterprises (BUMN) at central level and Local Government-Owned Enterprises (BUMD) in local level. The purposes of this research are, first, to determine the urgency of changing the status of a legal entity at the BUMD PDAM Tirta Pakuan of Bogor City into the form of Local Government Public Company (PERUMDA) in terms of Government Regulation Number 54 of 2017 concerning Local Government-Owned Enterprises (BUMD). Second, this study aims to find out the prospects for changing the status of Local Government corporate legal entities drinking water from Tirta Pakuan Bogor in order to improve drinking water services in the city of Bogor. This study was carried out using two types of research method, which are: (1) normative juridical research by examining library materials which are secondary data and also called library research, and (2) empirical juridical research, also called as field research, which is conducted through the means of interviews as primary data.
\end{abstract}

Keywords: Local Government; Local Government-Owned Enterprises (BUMD); Local Government Companies, Legal Entities

\section{Introduction}

Local Government-Owned Enterprises (BUMD) are business entities whose capital is (partly or wholly) owned by the region, and is the driving force for the economy in the region because it was established with the aim of providing benefits for local economic development, providing public services, and making profits (Republik Indonesia, 2014; 2017). The formation of Local Government Owned Enterprises (BUMD) is regulated in Law Number 23 of 2014 concerning Local Government. Law Number 23 of 2014 concerning Local Government changes the nomenclature and regulators of the status of legal entities compared to the previous provisions of Local Government Owned Enterprises or 
commonly abbreviated as BUMD. Article 1 number 40 of Law Number 23 Year 2014 concerning Local Government affirms that Local Government Owned Enterprises or BUMDs are "business entities whose capital is wholly or most of which are owned by region" (Republic of Indonesia, 2014). Article 331 paragraph (3) of Law Number 23 Year 2014 concerning Local Government regulates that BUMD can be a legal entity in two forms: (a) Local Government public company and (b) Local Government Limited Liability Company.

All this time, the regulations regarding BUMD are not fully comprehensive. In general, prior to Law Number 23 of 2014, the formation of BUMD PDAMs was based on Law Number 5 of 1962 concerning Local Companies which therein regulates the formation of Local Government companies with Local Government Regulations. The nature of a Local Government company based on Article 5 of Law Number 5 of 1962 is a production unit which (a) provides services; (b) provide public benefits; and (c) generate income.

Capital of Local Government company is the whole or part of the separated Local Government assets. If considered as shares, it is divided into priority shares and common shares, where the local government has priority shares (Republic of Indonesia, 1962). Local Government companies are led by directors whose number of members and composition are stipulated in its establishment regulations (Republic of Indonesia, 1962).

It is different from State-Owned Enterprises (BUMN) which is regulated in Law Number 19 Year 2003 concerning BUMN that divides BUMN into two forms: (1) BUMN in the form of public companies and (2) BUMN in the form of partnership. However, in the context of BUMD, so far, it has only been regulated in the form of a Local Government Company as regulated by Law Number 5 of 1962 concerning Local Government Companies.

However, apart from Law Number 5 of 1962, various laws and regulations have been issued such as Regulation of the Minister of Home Affairs Number 1 of 1998 concerning the Legal Form of Local Government Development Bank, Regulation of the Minister of Home Affairs Number 3 of 1998 concerning the Legal Forms of Local Government-Owned Enterprises, and Instruction of the Minister of Home Affairs Number 5 of 1990 concerning Changes in the Form of Local Government-Owned Enterprises into Two Forms of Local Government Public Companies and Local Government Limited Liability Companies. From these laws, the form of BUMD can be in the form of Regional Public Company (PERUMDA)/Regional Company or Limited Liability Company/Local Government Limited Liability Company. With the issuance of Law Number 40 of 2007 concerning Limited Liability Companies, based on Regulation of the Minister of Home Affairs Number 3 of 1998 above, in its operation, each BUMD is subject to legal provisions governing their respective legal entities. This, Local Government public companies or Local Government companies are subject to Law Number 5 of 1962 and for Local Government companies it is subject to Law Number 40 of 2007 concerning Limited Liability Companies.

The reality of the aforementioned statutory regulations has certainly become a problem in the context of legislative harmonization. First, at the statutory level there is actually only one law that clearly states the legal entity form of a BUMD, namely a Local Government company, even though Law Number 5 of 1962 does not use the term BUMD. What is interesting is that Law Number 5 of 1962 itself was later repealed and declared invalid by Government Regulation in Lieu of Law Number 6 of 1969 and then the government issued Regulation of the Minister of Home Affairs Number 3 of 1998 concerning BUMD. However, Local Government companies that have existed under Law Number 5 of 1962 are still enacted. Meanwhile, Local Government companies and Local Government public companies depart from statutory regulations under the law (such as the Instructions and Regulations Ministry of Home Affairs) so that their legal power can be debated (Hotma, 2010). 
Second, there is no legal unification regarding BUMD, unlike BUMN which is subject to Law Number 19 Year 2003 concerning BUMN which in detail regulates the form of its legal entity. Third, it cannot be denied that the influence of the political configuration of the law that is no longer relevant at this time is urgent for reform of legislation. As in the consideration regarding Law Number 5 of 1962 citing the Political Manifesto of the Republic of Indonesia dated August 17, 1959, which can no longer be used as a legal basis during the reform period (Zulmawan, 2015).

The issuance of Law Number 23 of 2014 concerning Local Government which codifies BUMD into two types, Local Government Public Companies and Regional Limited Liability Companies, which is a form of reinforcement to the legal dimension of regulating and recognizing BUMD in a more comprehensive manner. However, the problem is, the absence of a Government Regulation that further regulates the implementation of the BUMD legal form encourages a careful study so that there is no disharmony in the formation of Local Government regulations as the basis for BUMD and the implications of choosing the legal form of BUMD can be responded to in a manner adequate and comprehensive.

In the results of the initial review, so far, the formation of Local Government Owned Enterprises (BUMD) as a business owned by the local government has a clear objective, namely as a source of Local Government revenue (PAD). However, in its dynamics, there are always experiences of various challenges. First, there are BUMDs that still receive more cash injections from the local government than the profits, so they become a burden on the Local Government Revenue and Expenditure Budget (APBD). Second, from a legal aspect, BUMD is not like BUMN which has a specific legal umbrella in Law Number 19 of 2003. BUMD is still based on Local Government regulations and Law Number 5 of 1962 concerning Local Government Companies. Regulations of Minister of Home Affairs Number 3 of 1998 confirms that BUMD can be a Local Government company or a liability company. Third, there is question on whether financial status of BUMD remain a Local Government financial status or it has become a business entity. This will have an impact on the flexibility of policy making.

Essentially, Local Government-Owned Enterprises (BUMD) itself has a strategic role for the Local Government area considering its dual function as Local Government financial revenue (PAD) and provision of public services in the Local Government areas according to the type of business. Conceptually, Local Government-Owned Enterprises (BUMD) is a business entity that is wholly or most of the capital owned by the Local Government. With Local Government autonomy in an effort to improve the economy, BUMDs can be formed either for public service purposes, profit oriented or a combination of both (Kusumo, 2016).

One of the BUMDs in Bogor City is the Bogor City Water Company (PDAM) Tirta Pakuan. Institutionally, the form of a Local Government Company (PD) must be transformed into a PERUMDA or PERSERODA based on the Local Government Law and Government Regulation on BUMD. Currently, PDAM Tirta Pakuan Bogor City has a legal umbrella based on Local Government regulations Number 16 of 2011 on the Tirta Pakuan Local Government Drinking Water Company (PDAM) in Bogor City.

Referring to the provisions of Article 4 of Local Government Regulation Number 16 of 2011 above, it is clear that the elements of public service dominate the aims and objectives of the establishment of PDAM Tirta Pakuan Bogor City. However, it does not cover the boost in profit because it is a source of PAD. Thus, further analysis is needed if a legal entity status is to be repositioned, then the compatibility of PDAM's character and needs with its choice of legal entity needs to be aligned.

Such achievement must be institutionalized in the form of a legal entity that is able to maintain performance and even improve it. In the theoretical context above, the study of the choice of legal entities needs to be supported by efforts to encourage the character of legal products so that the legal concept is 
responsive in which the law is a means of responding to the needs and aspirations of the community, including in this case the institutional needs of the PDAM itself. Thus, from a legal perspective, in order to improve service quality, professional, integrous, and competitive organizations are needed so that the issuance of the Local Government Law and Government Regulation on BUMD opens opportunities for PDAM legal entity status to be reviewed and adjusted for legal entity status.

\section{Research Method}

Research is a principal means of developing science and technology. this is because research aims to reveal the truth systematically, methodologically, and consistently. This research is a normative legal research (doctrinal) through library research, which is research conducted by collecting data from various libraries related to the problem under study through the statue approach (Ibrahim, 2008, p. 30), namely the process of tracing Legislative products in terms of both the regulation and the legislative process (Marzuki, 2017, p.136). In addition, a conceptual approach is also used, namely studying various doctrines or legal views regarding antinomies in legal theory (Marzuki, 2017, p.136). The data needed is secondary data ${ }^{1}$, consisting of primary legal materials, namely legal materials that are binding (AshShofa, 2007, p.103), including statutory regulations. Secondary legal materials are legal materials that provide an explanation of primary legal materials (AshShofa, 2007, p. 103), which consists of various references both books, research results, scientific journals relevant to the object of this research. Meanwhile, tertiary legal materials are legal materials that provide clarity of secondary legal materials in the form of an Indonesian Language Dictionary and a Legal Dictionary (Black's Law Dictionary).

The data was collected through document or literature study by examining the data obtained in the form of library materials or documents that are relevant to the problem under study. After the data collection process, the next stage is data processing. Marzuki (2007) in his book Legal research mentions research steps. These steps include identifying legal facts and eliminating irrelevant matters in order to determine the legal issue to be resolved, gathering relevant legal materials, analyzing legal issues submitted based on the materials that have been collected, drawing conclusions. in the form of arguments that answer legal issues, providing prescriptions based on the arguments that have been built into the conclusions (Marzuki, 2007, p. 171).

\section{Analysis and Discussion}

\section{Nature of Legal Entities}

It is often said that if a legal entity is called a person created by humans (or by human creation law), then human (as a legal subject) is a person created by God. In this sense, God created humans, and humans created legal entities. For the two model persons (human or legal entity), there are several similarities as follows (Fuady, 2014, p. 166):

1. Having a rational attitude;

2. Having his own attitude and personality;

3. Have a need to live;

4. Own property, rights and obligations;

5. Have legal responsibility, even including criminal responsibility.

However, even though at the time the legal regime did not officially recognize the existence of an association as a legal entity, many legal theories or other legal institutions were applied as addition. These

1 Secondary data is data obtained from library material covering official documents, books, research reports, and journal (See Soekanto, 2007, p. 12). 
are the legal theories or legal institutions that cover this deficiency, although not treating the association as a legal entity, considered it equal with a "semi legal entity", which causes an association to function as a holder of rights, obligations, and responsibilities.

Many terms are given for a legal entity. In Indonesian, there is only the term "legal entity", or sometimes referred to as the term "korporasi" which is an Indonesian term for corporate or corporation. However, in other languages of the world there are various kinds of terms for legal persons. Furthermore, it is necessary to know what exactly is meant by a legal entity. What is meant by a legal entity is an organization, body, group, institution, or property, which is established or confirmed by law, is intended as a holder of rights, authorities, obligations, assets, duties, status, privileges which are principally separated from those owned by an individual human being. Legal entities have a manager who represents and carries out the interests of the legal entity as well as the interests of its members, so that the legal entity can sue or be sued in front of a court, as well as being a victim of a criminal act even in its modern sense. Furthermore, legal entity can also commit a criminal act and be punishable by crime. Thus, it can be said that a legal entity is a right-and-duty bearing unit in form of bodiless and soulless human (Fuady, 2014, p. 167).

Although a legal entity can finally be held responsible separately from the personal responsibility of its founder, owner, or members, not all of the powers given to private persons must also be given to a legal entity. According to Fuady (2014, p. 169), this is due to the following factors.

1. There are private human activities that are impossible for a legal entity to do. For example, a legal entity cannot marry or bear children, so almost all family laws or inheritance laws do not apply to a legal entity.

2. There are certain rights that are only inherent in individual humans, and therefore are not attached to legal entities. For example, human rights are attached to individuals, so that they need to be protected which in principle do not exist or are not the same as those given to legal entities. For example, the right to life, the right to health facilities, education, and freedom of religion. However, on the other hand, there are also various kinds of human rights which to some extent also apply to legal entities. For example, the right to be enforced equally in law, the principle of presumption of innocence, the right to self-defense, the right to a lawyer, the right not to have assets taken by the government without adequate compensation, and freedom of speech. In fact, the European Convention on Human Rights has explicitly extended the application of fundamental human rights to legal entities, where violations by member states of these human rights can be sued in the European court of human rights in Strasbourg.

3. There are certain statuses that can only be assigned to individuals, but not suitable for legal entities. For example, with the status of a citizen, an individual human has the right to vote or be elected in a fair general election.

4. There are certain positions that can only be given to individuals and cannot be given to a legal entity. For example, a position to hold a position in government or public offices.

5. In the case of a criminal offense committed by a legal entity, there are models of punishment which are only appropriate for private persons but not suitable for legal entities. For example, imprisonment, detention, imprisonment, flogging, the death penalty by being shot, hanged, beheaded, electric chair or lethal injection.

6. The existence of civil or criminal actions that can be committed against a legal entity, with different sociological consequences if it is carried out by or against an individual, so that the legal consequences will be different. For example, in several countries. Acts of defamation which harm a legal entity are regulated differently from defamation of individuals. For example, compensation for acts of defamation against a legal entity is only for material loss, while for individuals, both for material loss and immaterial loss. 
Theoretically, the emergence of state-owned and local government owned enterprises departs from the existence of the state's authority to prosper its citizens through state-run business services. When examined from the rule of law theory, the emergence of the state in the context of participating in the economy of society stems from the criticism in the 19th century against the teachings of the classical rule of law.

The term BUMD itself departs from a legal basis in the form of the issuance of Government Regulation Number 12 of 1998 and Government Regulation Number 13 of 1998. However, the term BUMD has not yet been established by statutory standards. It is different from BUMN which definition has been stipulated by Law Number 19 of 2003 concerning BUMN. On the other hand, the term BUMD has been well contained in the Minister of Home Affairs Regulation Number 3 of 1999 concerning the Legal Form of BUMD. In addition, it is also stated in Law Number 22 of 1999 which was replaced by Law Number 32 of 2004 concerning Local Government, including Law Number 23 of 2014 concerning Local Government. In addition, there are various sectoral laws such as the State Treasury Law, the Electricity Law, the Mineral and Coal (MINERBA) Law, the Shipping Law, the Road Law, and so on which allude to the legal form of BUMD.

What is interesting is that until now the establishment and regulation of BUMDs are still subject to Law Number 5 of 1962 concerning Local Government Companies even though this law has been repealed by Law Number 6 of 1969, because it emphasizes that Law Number 5 of 1962 does not take effect since the issuance of the replacement law, and until now there has been no substitute law. Therefore, Law Number 5 of 1962 is still in effect today. With the issuance of Law Number 23 of 2014 concerning Local Government, Law Number 5 of 1962 urges to be reviewed. The problem is Law Number 23 Year 2014 has not yet published a technical regulation regarding Regional Companies at the Government Regulation level so that it results in lack of clarity in implementation in the regions.

To date, the regulations regarding BUMD are not fully comprehensive. In general, prior to Law Number 23 of 2014, the formation of BUMD PDAMs was based on Law Number 5 of 1962 concerning Local Government Companies. Therein regulates the formation of Local Government companies with Local Government Regulations. The nature of a Local Government company based on Article 5 of Law Number 5 of 1962 is a production unit which: (a) provides services; (b) provide public benefits; and (c) generate income.

Capital of Local Government company is all or part of the separated Local Government assets. If the shares are divided into priority shares and common shares, where the local government has priority shares as described in Article 8 of Law Number 5 of 1962 concerning Local Government Companies. In Article 11, it is explained that Local Government companies are led by directors whose number of members and composition are stipulated in their establishment regulations.

After the issuance of Law Number 23 of 2014 concerning Local Government, the BUMD nomenclature was formulated and regulated in its articles. Article 1 number 40 of Law Number 23 Year 2014 confirms, Local Government Owned Enterprises or BUMDs are "business entities whose capital is wholly or mostly owned by regions" (Republik Indonesia, 2014). Article 331 paragraph (3) of Law Number 23 Year 2014 stipulates that BUMD can be a legal entity in form of (a) Local Government Public Company and (b) Local Government Limited Liability Company. The reasons for its formation are regulated in Article 331 paragraph (5) of Law Number 23 of 2014, which can be based on (a) local needs and (b) the feasibility of the BUMD business sector to be formed. The source of capital is regulated in Article 332 and Article 333 of Law Number 23 Year 2014 which are the participation of local capital, loans, grants, and other capital. If local capital is included, it must be stipulated by a Local Government Regulation (PERDA). With the issuance of Law Number 23 of 2014 concerning Local Government, BUMD regulation is subject to Law Number 23 of 2014 in accordance with the principle of legal preference where the new legal rules override the old legal rules in this case Law Number 5 of 1962 
regarding Local Companies (apart from being affirmed in Article 409 letter a of the Local Government Law that Law Number 5 of 1962 concerning Local Companies is revoked and declared invalid).

If tracing Article 331 paragraph (1) of Law Number 23 of 2014 concerning Local Government, the norm used is "can". The details are as follows: "Regions can establish BUMD". Continued in paragraph (2), "The establishment of BUMD as referred to in paragraph (1) is stipulated by a Local Government Regulation" (Republik Indonesia, 2014). It is continued in paragraph (3), "BUMD as referred to in paragraph (1) consists of Local Public Companies and Local Government Companies" (Republik Indonesia, 2014)..Based on the description above, the establishment of a BUMD (including changing the status of a legal entity to a Local Public Company and a Local Government Public Company) is in principle a choice of legal policies from the Local Government. This is indicated by the use of the "can" norm. However, in paragraph (5) of Article 331 of the Local Government Law, there is an affirmation that the establishment of the BUMD above must be based on fulfillment of two things, which are (a) Local Government needs and (b) the feasibility of the BUMD business sector to be formed. In this context, it is necessary to study in depth, especially regarding local needs, because PDAM Tirta Pakuan is already feasible and plays an important role in fulfilling the need for drinking water in Bogor City.

Essentially, Local Government Owned Enterprises (BUMD) has a strategic role for the local area considering its dual function which are providing local financial revenue (PAD) and public services in the local area according to the type of business. Conceptually, Local Government Owned Enterprises (BUMD) is a business entity that is the whole or most of the capital owned by the local government. So far, Local Government Owned Enterprises (BUMD) is formed as business owned by the local government, with a clear objective, to be the source of Local Government revenue (PAD). However, in the dynamic, it always experiences various challenges. First, there are still BUMDs that receive more cash injections from the Local Government than the profits, so they become a burden on the APBD. Second, from a legal aspect, BUMD is not like BUMN which has a specific legal umbrella in Law Number 19 of 2003, it is still based on Local Government regulations and Law Number 5 of 1962 concerning Local Government Companies. Regulation of Minister of Home Affairs Number 3 of 1998 confirms that the BUMD can be a local government company or a liability company.

Based on the provisions of Article 331 paragraph (6) of Law Number 23 of 2014 concerning Local Government concerning the provisions of BUMD as referred to in paragraph (1) are regulated in a Government Regulation. This is related to the plan to change the status of a legal entity from a PDAM to a PERUMDA (which is regulated in a Local Government Regulation). It is necessary to consider changing the legal entity status of the PDAM to Perumda Tirta Pakuan Drinking Water in Bogor City which was formed by a Local Government Regulation (PERDA) in order to prevent a legal vacuum (rechtsvac) after the revocation and the non-enactment of Law Number 5 of 1962 concerning Local Government Companies which during this forms the basis for the legal form of the Local Government Company. However, if in the future a Government Regulation is issued in order to further regulate BUMD (including the technical operationalization of legal entities either PERUMDA or Local Government Limited Liability Companies) as mandated by Article 331 paragraph (6) of Law Number 23 of 2014 concerning Local Government, then it is better if the local government regulation regarding the change in the legal entity status of the PDAM to Perumda Tirta Pakuan Drinking Water in Bogor City is obliged to comply with the intended Government Regulation.

\section{Analysis of Legislation}

In the context of the legal system, various statutory regulations become the legal basis for a hierarchical compulsory basis as mandated by Article 7 paragraph (1) of Law Number 12 Year 2011 concerning the Formation of Legislation. The hierarchical system is an extension of every type of statutory regulation based on the principle that lower statutory regulations must not conflict with 
higher statutory regulations. Therefore, it is necessary to pay attention to the principles of legal harmonization and legal synchronization so that there is no material conflict between the laws and regulations.

The drafting of the Local Government Regulation Draft on the City of Bogor concerning the Local Public Company for Drinking Water Tirta Pakuan in Bogor City departs from the need for legal harmonization and synchronization and is expected to have an impact on the quality of company services. Since the issuance of Law Number 23 of 2014 concerning Local Government, the BUMD nomenclature gets the formulation and regulation of its articles. Article 1 Number 40 of Law Number 23 Year 2014 concerning Local Government confirms, Local Government Owned Enterprises or BUMDs are "business entities whose capital is wholly or largely owned by regions" (Republik Indonesia, 2014). Article 331 paragraph (3) of Law Number 23 Year 2014 concerning Local Government regulates that BUMDs can be legal entities (a) Local Public Companies and (b) Local Government Companies. The reasons for its formation are regulated in Article 331 paragraph (5) of Law Number 23 of 2014 concerning Local Government, which can be based on (a) Local Government needs and (b) the feasibility of the BUMD business sector to be formed. The source of capital in Article 332 and Article 333 of Law Number 23 Year 2014 concerning Local Government is regulated, namely the participation of Local Government capital, loans, grants and other capital. If Local Government capital is included, it must be stipulated by a Local Government Regulation.

The idea of changing the status of a Local Government Legal Entity to a Local Government Public Company at PDAM Tirta Pakuan Bogor City is a legal policy option that can be implemented to overcome the legal vacuum, as long as it is regulated under the legal umbrella of Local Government Regulations in accordance with Article 331 paragraph (1) of the Law Number 23 of 2014 concerning Local Government with due regard to the issuance of a Government Regulation which regulates the technicalities of Local Public Companies based on Article 331 paragraph (6) of Law Number 23 of 2014 concerning Local Government, the Local Government Regulation regarding the status of a Local Public Company legal above must adjust with the substance of the said Government Regulation.

\section{Conclusion}

After the issuance of Law Number 23 of 2014 concerning Local Government, the BUMD nomenclature was formulated and regulated in its articles. Article 1 number 40 of Law Number 23 Year 2014 confirms, Local Government Owned Enterprises or BUMDs are "business entities whose capital is wholly or mostly owned by regions." Article 331 paragraph (3) of Law Number 23 Year 2014 stipulates that BUMD can be a legal entity (a) Local Government Public Company and (b) Local Government Limited Liability Company. The reasons for its formation are regulated in Article 331 paragraph (5) of Law Number 23 of 2014, which can be based on (a) Local Government needs and (b) the feasibility of the BUMD business sector to be formed. The source of capital in Article 332 and Article 333 of Law Number 23 Year 2014 is regulated, namely the participation of Local Government capital, loans, grants and other capital. If local government capital is included, it must be stipulated by a Local Government Regulation. With the issuance of Law Number 23 of 2014 concerning Local Government, BUMD regulation is subject to Law Number 23 of 2014 in accordance with the principle of legal preference where the new legal rules override the old legal rules in this case Law Number 5 of 1962 regarding Local Government Companies (apart from being affirmed in Article 409 letter a of Law Number 23 of 2014 concerning Local Government, that Law Number 5 of 1962 concerning Local Government Companies is revoked and declared invalid).

The idea of changing the status of a Local Government Legal Entity to a Local Government Public Company at PDAM Tirta Pakuan Bogor City is a legal policy option that can be implemented to 
overcome the legal vacuum, as long as it is regulated under the legal umbrella of Local Government Regulations in accordance with Article 331 paragraph (1) of the Law Number 23 of 2014 concerning Local Government with due regard to the issuance of a Government Regulation which regulates the technicalities of Local Government Public Companies based on Article 331 paragraph (6) of Law Number 23 of 2014 concerning Local Government. The Local Government Regulations regarding the status of a Local Government Public Company legal above must adjust with the substance of the said Government Regulation.

\section{References}

Ashshofa, B. (2007). Metode Penelitian Hukum [Legal Research Methods]. Jakarta: Rineka Cipta.

Fuady, M. (2014). Teori-Teori Besar (Grand Theory) Dalam Hukum [Grand Theory in Law]. Jakarta: Kencana Prenamedia Group.

Hotma, B. R. S. (2010). "Permasalahan Hukum Atas Bentuk Badan Hukum Pada Badan Usaha Milik Daerah [Legal Issues Over the Form of Legal Entities in Local Government Owned Enterprises]", Kajian, 15(4), pp. 751-781.

Ibrahim, J. (2008). Teori, Metode Dan Penelitian Hukum Normatif [Theory, Methods and Normative Law Research]. Malang: Bayumedia Publishing.

Kusumo, D. T. (2016). "Kajian Yuridis Bentuk Badan Usaha Milik Daerah Di Bidang Perbankan Pasca Berlakunya Undang-Undang Nomor 23 Tahun 2014 tetang Pemerintahan Daerah [Juridical Study on the Forms of Local Government-Owned Enterprises in the Banking Sector after the enactment of Law Number 23 of 2014 concerning Local Government]", Privat Law, 4(1), pp. 21-29..

Marzuki, P. M. (2007). Penelitian Hukum (Edisi Pertama) [Legal Research (First Edition)]. Jakarta: Kencana.

Marzuki, P. M. (2017). Penelitian Hukum (Edisi Revisi) [Legal Research (Revision Edition)]. Jakarta: Kencana.

Republik Indonesia. (1962). Undang-Undang Nomor 5 Tahun 1962 tentang Perusahaan Daerah [Law Number 5 of 1962 concerning Local Government Company]. Jakarta: Sekretariat Negara Republik Indonesia.

Republik Indonesia. (2014). Undang-Undang Nomor 23 Tahun 2014 tentang Pemerintahan Daerah [Law Number 23 of 2014 concerning Local Government]. Jakarta: Sekretariat Negara Republik Indonesia.

Republik Indonesia. (2017). Peraturan Pemerintah Nomor 54 Tahun 2017 Tentang Badan Usaha Milik Daerah [Law Number 54 of 2017 concerning Local Government Owned Enterprise]. Jakarta: Sekretariat Negara Republik Indonesia.

Soekanto, S. (2007). Pengantar Penelitian Hukum [Introduction to Legal Research]. Jakarta: UI Press. Zulmawan, W. (2015). Kenapa Harus BUMD [Why Must BUMD?], Jakarta: Jala Permata Aksara.

\section{Copyrights}

Copyright for this article is retained by the author(s), with first publication rights granted to the journal.

This is an open-access article distributed under the terms and conditions of the Creative Commons Attribution license (http://creativecommons.org/licenses/by/4.0/). 